\title{
THE RECIPROCAL EFFECT OF LEVERAGE, DIVIDEND POLICY, AND FINANCIAL PERFORMANCE: STUDY ON COMPARISON BETWEEN MINING AND TRADE, SERVICES, INVESTMENT COMPANIES LISTED ON INDONESIA STOCK EXCHANGE PERIOD OF 2010-2014
}

\author{
Sonia Machfiro ${ }^{1 *}$, Eko Ganis Sukoharsono ${ }^{2}$, Nila Firdausi Nuzula ${ }^{1}$ \\ ${ }^{1}$ Faculty of Administrative Science, University of Brawijaya, Indonesia \\ ${ }^{2}$ Faculty of Economics and Business, University of Brawijaya, Indonesia \\ *E-mail: soniamachfiro@rocketmail.com
}

\begin{abstract}
The purpose of this research is empirically examine the effect of leverage, dividend policy, and financial performance reciprocally and to know the difference application on the companies that have high and low liabilities level in Indonesia. The object of this research is using publicly traded companies listed in Indonesia Stock Exchange (IDX) in period of 2010 2014 of Mining Companies which has the highest average corporate liabilities of all sectors and Trade, Service, Investment Companies which has the lowest average corporate liabilities. The population of this research are all public Mining and Trade, Service, and Investment companies listed in Indonesia Stock Exchange (IDX) in period of 2010-2014 with sample 6 Mining Companies, and 6 Trade, Service, Investment Companies. The research analysis using GSCA (Generalized Structured Component Analysis). The research results show that leverage has insignificant effect on dividend policy reciprocally both on Mining and Trade, Service, Investment Companies. Leverage has significant effect on the financial performance reciprocally both on Mining and Trade, Service, Investment Companies. Dividend policy has significant effect on the financial performance reciprocally on Mining Companies. However, Dividend policy has insignificant effect on the financial performance reciprocally on Trade, Service, Investment Companies.
\end{abstract}

\section{KEY WORDS}

Leverage, dividend policy, financial performance, mining companies, trade service investment companies.

Every company aims to maximize its value and it will be achieved if the company has sufficient funds to meet its operational activities, both through internal or external financing. The combination of internal and external financing is called capital structure. Several factors such as corporate tax, bankruptcy cost, and personal tax, have been proposed to explain why a company ultimately chose a particular capital structure (Brigham, 1999). For a company, finding the right capital structure involves finding the right amount of financial leverage. Financial leverage is using fixed obligation to finance companies' asset and internal operations.

Internal financed companies using their profits as source of capital for new investment rather than distributing them to stockholders or obtaining capital from outside companies. However, internal financing is very limited which will constrain business to expand. In order to maximize its value, companies need external funding that is acquired from sources outside the company such as leverage. A little gesture by managers to add leverage to the capital structure can boost up the profitability of a company (Syamsuddin, 2007).

Sources of funding in a company could affect its dividend policy and/or financial performance as mentioned in several studies such as Yulianto (2014), Siahaan (2014), Purnomosidi (2014), and Darmawan (2011). Companies can use external funding to finance dividend payment if they are experiencing lack of internal funding. In the other hand, if the companies use leverage, the creditors could possibly constrain dividend payment in order to prevent business risks and wealthy transfer from creditors to stockholders. Relate to financial 
performance, leverage could also favorable if the company capable to balance the tax shield and interests as proposed in Trade off theory (Myers, 1984).

The study of this research is comparing the highest and the lowest corporate liabilities level in Indonesia companies that listed in Indonesia Stock Exchange because liabilities are substantial aspect of a company's operations and are used to finance operations, to pay dividends and large expansions, in order to enhance their financial performance. Liabilities able to make transactions between businesses more effective and efficient, for instance the outstanding money which companies owe to their suppliers would be considered as liability. Each industry has its own benchmarks for liabilities. Based on Indonesia Stock Exchange Data, Mining Sector has the highest average liabilities while Trade, Services and Investment Sector has the lowest average liabilities as shown in figure 1 below.

\section{LIABILITIES AVERAGE IN SECTORS LISTED IN IDX} (2010-2014)
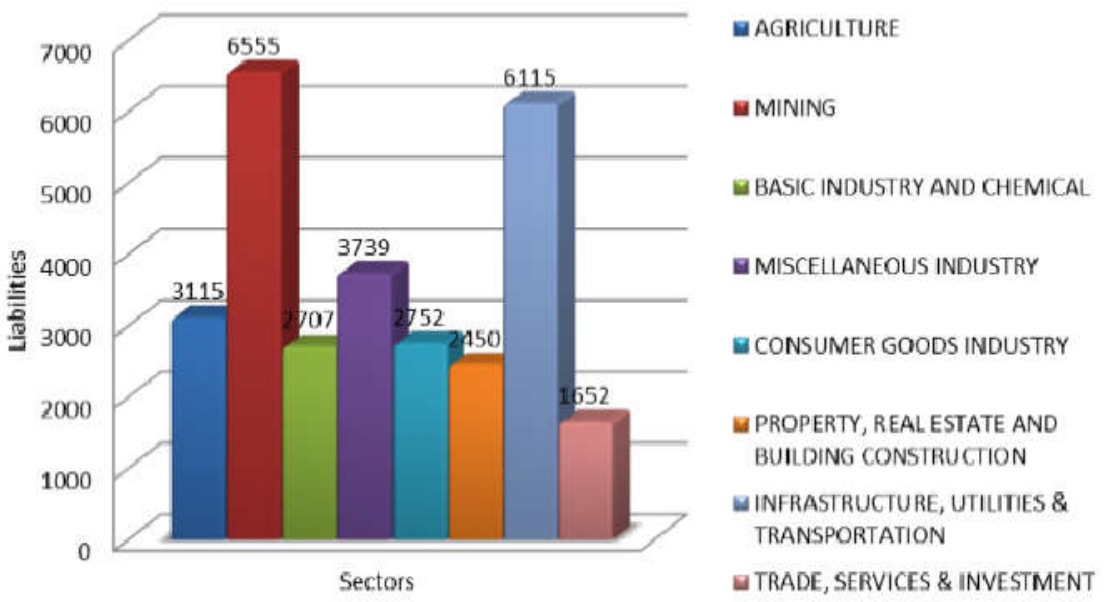

Source: Processed data, 2016.

Figure 1 - The Liabilities Average in Each Sectors Listed in IDX (In Billions Rupiah)

The mineral resources sector plays a significant part in the Indonesian economy. Based on mining legislation and policies research by Devi and Prayogo (2013) mining contributes roughly five percent of the total Indonesian Gross Domestic Product (GDP) and a much greater contribution within the regional economies of some resource-prosperous provinces. Mining industry also engage many investors, such as China, India, Russia and South Korea. Indonesia has extensive mineral reserves and has become the world's largest exporter of thermal coal, as well as second in tin, third in copper and fourth in nickel (Lieokomol, 2011). The mining prospects of Indonesia is high because of the country's extensive mineral reserves and exploration activities.

The first TSI industry is Trade companies. Based on Indonesia Stock Exchange classification, trade companies consist of Wholesale (Durable and Non-Durable Goods) and Retail Trade. Trading company is dealing with different types of goods that are offered to consumers, enterprises, and government. Trading companies purchase a certain quantity of goods, store it, and deliver it to the customers.

The second TSI industry is service company. Based on Indonesia Stock Exchange classification, service companies consist of Tourism, Restaurant, And Hotel; Advertising, Printing, And Media; Health Care; and Computer and Services. Service company is a commercial enterprise that provides work and performed in a professional manner by a person or a team for the benefit of its clients. The difference with another type of companies is service companies do not actually sell products, generally they do not have inventory on their balance sheets because they do not own any. 
The third TSI industry is investment company. Investment company is a business entity that manage, sell, and market funds to the public. Investment company generally offer investors a range of funds and investment services, which include portfolio management, recordkeeping, accounting, legal, and tax management services.

This research is analyzing reciprocal effect among variables. The reciprocal effect analysis is mutual influences study between two or more variables. Often, researchers attribute causality to the influences among variables and speak reciprocal causal effects. Longitudinal data are crucial to the analysis of reciprocal effect, because temporal ordering is needed to express the influences linking the variables. Longitudinal data means that the process of gathering sample is in a given period of time. The reason why this research analysis is reciprocal because based on previous researches, leverage, dividend policy, and financial performance is interrelated, and also there are no previous researches that ever examined those variables reciprocally.

In order to empirically examine the effect of leverage, dividend policy, and financial performance reciprocally and to know the difference application on the industries that have the highest and the lowest corporate liabilities level in Indonesia companies, then the object of this research is using publicly traded companies listed in Indonesia Stock Exchange of Mining Sector which has the highest corporate liabilities of all sectors and Trade, Service, and Investment Sector which has the lowest corporate liabilities.

Research Questions. Based on the description in the background above, the research questions are:

1. Does leverage have significant effect on dividend policy reciprocally?

2. Does leverage have significant effect on financial performance reciprocally?

3. Does dividend policy have significant effect on financial performance reciprocally?

Research Objectives. Based on research questions above, then the objectives of this research are:

1. Analyzing and explaining the significant effect of leverage on dividend policy reciprocally;

2. Analyzing and explaining the significant effect of leverage on financial performance reciprocally;

3. Analyzing and explain the significant effect of dividend policy on financial performance reciprocally.

\section{LITERATURE REVIEW}

Leverage. Leverage is an external source of funding which companies acquire from external party such as creditors, banks, and other financial institutions to buy more assets and expect more profits or asset appreciation more than the cost of borrowing because company must repay the debt installment plus interest in a predetermined time.

Debt Equity Ratio (DER) is a measurement tool that represents a part of company's equity that are financed by debt. A higher debt equity ratio means that a company is more aggressive in financing its growth with debt. Aggressive leveraging practices most of the time is correlated with high levels of risk. This may result in unstable or volatile earnings as a result of further interest expense. Some previous research such as Al-Malkawi (2008); Khan (2013); Ardestani (2013); and Vo and Nguyen (2014) stated that debt equity ratio is leverage indicators.

Debt Ratio (DR) is a measurement tool that represents a proportion of debt to finance company's assets. The higher Debt Ratio, the more leveraged the company, and the greater its financial risk. In the other hand, leverage is important for companies to develop and grow. Some previous research such as Adedeji (2008); Asif et al. (2011); Darmawan (2011); and Rizqia et al. (2013) stated that debt ratio represents leverage indicators.

Long Term Debt per Total Asset (LTDA) is a measurement tool that represents a part of company's assets that are financed with long term loans and financial obligations that lasting more than a year. The lower LTDA means that the company is progressively 
becoming less dependent on debt to develop and grow their business. Emamalizadeh et al. (2013) stated that Long Term Debt per Total Asset also represents leverage indicators.

Based on previous researches, measurements of leverage are: 1) Debt Equity Ratio (DER); 2) Debt Ratio (DR); and 3) Long Term Debt per Asset (LTDA) as described in table 1 below:

Table 1 - Measurement of Leverage

\begin{tabular}{|c|c|c|}
\hline No & Measurements & Formula \\
\hline 1 & DER & DER $=\frac{\text { Total Debt }}{\text { Equity }}$ \\
\hline 2 & DR & DR $=\frac{\text { Total Debt }}{\text { Total Asset }}$ \\
\hline 3 & LTDA & LTDA $=\frac{\text { Long Term Debt }}{\text { Total Asset }}$ \\
\hline
\end{tabular}

Source: Summary of previous researches.

Dividend Policy. Dividend is distribution of company's income (issued as cash payments, shares of stock, or other property) to the stockholders which is decided by the board of directors. Managers have two alternatives to do with company net income, those are to distribute to the stockholders in the form of dividends, or reinvests to the company as retained earnings.

Dividend Per Share (DPS) is total dividend distribution divided by the number of outstanding ordinary shares issued. Dividend is a form of profit distribution to the stockholder, means a growing dividend per share can be a sign that company has growing profit and the company growth can be sustained. Several researches such as Asif et al. (2011); Emamalizadeh et al. (2013); Mosavi et al (2012); Yegon (2014); and Yulianto (2014), one of dividend policy indicators is dividend per share.

Dividend Payout Ratio (DPR) is a measurement tool that represents how much money a company is returning to stockholders, versus how much money company is keeping on hand to reinvest in growth, pay off debt, or add to cash reserves. Several researches such as Adedeji (2008); Subramaniam and Shaiban (2012); Khan (2013); Rizqia et al. (2013); and Yulianto (2014) stated that dividend payout ratio is dividend policy indicator.

Dividend Yield (DY) is a measurement tool that represents how much cash flow a company get for each dollar invested in an equity position. In the absence of capital gains, dividend yield is the return on investment for a stock. Several researches such as Adedeji (2008); Ardestani (2013); and Yulianto (2014) stated that dividend yield is dividend policy indicators.

Based on previous researches, measurements of dividend policy are: 1) Dividend Per Share (DPS); 2) Dividend Payout Ratio (DPR); and 3) Dividend Yield (DY) as described in table 2 below:

Table 2 - Measurement of Dividend Policy

\begin{tabular}{|c|c|c|}
\hline No & Measurements & Formula \\
\hline 1 & DPS & DPS $=\frac{\text { Dividend }}{\text { Share }}$ \\
\hline 2 & DPR & DPR $=\frac{\text { Dividend }}{\text { Net Income }}$ \\
\hline 3 & DY & DY $=\frac{\text { Dividend Per Share }}{\text { Price Per Share }}$ \\
\hline
\end{tabular}

Source: Summary of previous researches.

Financial Performance. Financial performance is companies' measurement tools of its policy and operational activity to understand how good they can utilize assets to generate revenues. Based on Kaplan Financial Knowledge Bank, traditionally, financial performance measurement is calculating profitability, liquidity / working capital, gearing, or investor ratios. 
Return on Equity (ROE) is a measurement tool that represents how profitable a company relative to its stockholder's equity. ROE is also useful for comparing the profitability of a company to the other firms in the same industry. Averaging ROE over the past years can give a better idea of the historical growth. The higher ROE, the better. Based on previous research such as Siahaan et al. (2014) and Purnomosidi et al. (2014) return on equity is financial performance indicator.

Return on Asset (ROA) is a measurement tool that represents how profitable a company relatively to its total assets. The asset of a company consists of debt and equity. Both of these types of financing are used to fund the company operational activities. ROA shows how effective a company is converting its money into net income. The higher ROA, the better, because the company is earning more money on less investment. Based on previous research such as Khan (2013); Rizqia et al. (2013); Siahaan et al. (2014); and purnomosidi et al. (2014) one of financial performance indicators is return on asset.

Net Profit Margin (NPM) is a company's measurement tool that calculating how much of each dollar earned by the company that is translated into profits. A low net profit margin may be interpreted as insecure company's profitability. Net profit margin may also indicate certain things about a company's ability to manage its expenses. High expenditures may indicate that a company is struggling to keep its costs low, whether a higher profit margin indicates a more profitable company that has better control over its costs compared to its competitors. Several previous researches such as Khan (2013); Siahaan et al. (2014); and Purnomosidi et al. (2014) stated that Net Profit Margin (NPM) is Financial Performance indicator

Based on previous researches, measurement of financial performance are: 1) Return on Equity (ROE); 2) Return on Asset (ROA); and 3) Net Profit Margin (NPM); as described in table 3 below:

Table 3 - Measures of Financial Performance

\begin{tabular}{|c|c|c|}
\hline No & Measurements & Formula \\
\hline 1 & ROE & ROE $=\frac{\text { Net Income }}{\text { Shareholder's Equity }}$ \\
\hline 2 & ROA & ROA $=\frac{\text { Net Income }}{\text { Total Asset }}$ \\
\hline 3 & NPM & NPM $=\frac{\text { Net Income }}{\text { Revenue }}$ \\
\hline
\end{tabular}

Source: Summary of previous researches

\section{CONCEPTUAL FRAMEWORK AND HYPOTHESIS}

Conceptual Framework. Research conceptual framework is the elaboration of research questions that has been described in previous chapter. The conceptual framework in this research is developed from dividend irrelevant theory proposed by Miller and Modigliani (1961) regarding to controversy between dividend in influencing the firm value that will relate to the company's financial performance. Based on the above explanation and the previous section, the research concept used in this research is as follows:

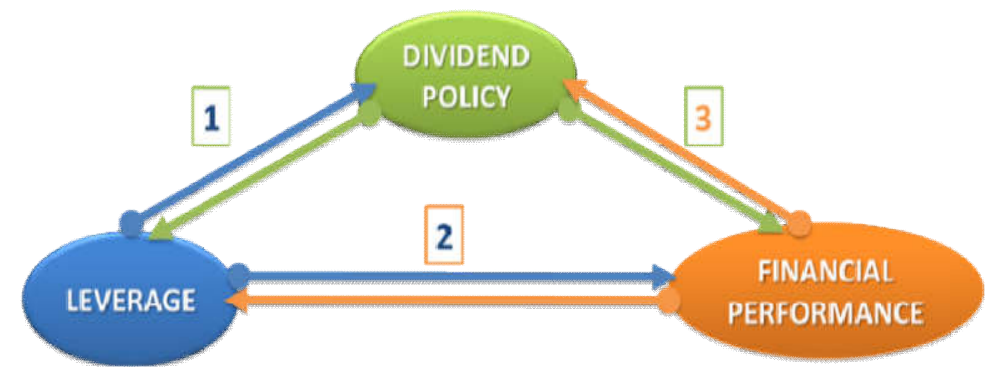

Source: Processed data, 2016.

Figure 2 - Conceptual Framework 
Table 4 - Description of Research Conceptual Framework

\begin{tabular}{|c|c|}
\hline No & Theory and Previous Researches \\
\hline \multirow[t]{3}{*}{ 1a. } & Leverage $\rightarrow$ Dividend Policy \\
\hline & Theory: Debt Covenant Hypothesis (Kalay, 1982) \\
\hline & Previous Research: Al-Malkawi (2008); Ari Darmawan (2011); Rizqia et al., (2013); Mosavi et al. (2012); \\
\hline \multirow[t]{3}{*}{$1 \mathrm{~b}}$. & Dividend Policy $\rightarrow$ Leverage \\
\hline & Theory: Monitoring Hypothesis (Easterbrook, 1984) \\
\hline & Previous Research: Wang et al. (2013); \\
\hline \multirow[t]{3}{*}{$2 a$. } & Leverage $\rightarrow$ Financial Performance \\
\hline & Theory: The Trade-off Theory (Myers, 1984) \\
\hline & Previous Research: Prem (2011); Alzomaia and Al-Khadhiri (2013); Jahanzeb (2014) \\
\hline \multirow[t]{3}{*}{ 2b. } & Financial Performance $\rightarrow$ Leverage \\
\hline & Theory: Pecking Order Theory (Myers and Majluf, 1984) \\
\hline & Previous Research: Amidu (2007) \\
\hline \multirow[t]{3}{*}{$3 a}$. & Dividend Policy $\rightarrow$ Financial Performance \\
\hline & Theory: Bird in The Hand Theory (Gordon, 1963) and \\
\hline & $\begin{array}{l}\text { Previous Research: (Lintner, 1962); Amidu (2007); Borges (2008); Alzomaia and Al-Khadhiri (2013); } \\
\text { Yegon (2014) }\end{array}$ \\
\hline \multirow[t]{3}{*}{$3 \mathrm{~b}}$. & Financial Performance $\rightarrow$ Dividend Policy \\
\hline & Theory: Dividend Signaling Hypothesis (Bhattacharya, 1979) \\
\hline & Previous Research: Amidu (2007); Khan (2013); Rizqia (2013), \\
\hline
\end{tabular}

Source: Processed data, 2016

Based on literature review, conceptual framework and results of previous studies, the research hypothesis are as follows:

$\mathrm{H} 1$ : Leverage has significant effect on dividend policy reciprocally;

$\mathrm{H} 2$ : Leverage has significant effect on financial performance reciprocally;

H3: Dividend policy has significant effect on financial performance reciprocally.

\section{METHODS OF RESEARCH}

Type of Research. The type of research is explanatory that explains the effect of leverage, dividend policy, and financial performance which provide causal explanations, or the effect between variables through hypothesis testing.

Research Location. The location of this research is Mining Sector Companies which has the highest corporate liabilities of all sectors and Trade, Service, and Investment Sector Companies which has the lowest corporate liabilities that listed on the Indonesia Stock Exchange in 2010 - 2014. The analysis unit of this research are Mining Sector Companies and Trade, Service, and Investment Sector Companies that listed on the Indonesia Stock Exchange with data from performance summary from Indonesia Stock Exchange (IDX) and audited financial statement.

Population and Sample. Population in this research is all public Mining Companies and Trade, Service, and Investment Companies that are listed in Indonesia Stock Exchange in 2010-2014 in order to know the different application on the industries that have the highest and the lowest corporate liabilities level in Indonesia companies.

Table 5 - Population of Mining companies listed on IDX in 2010-2014

\begin{tabular}{|c|l|c|c|c|c|c|}
\hline No & \multicolumn{1}{|c|}{ Subsector } & 10 & 11 & $' 12$ & $' 13$ & $' 14$ \\
\hline 1 & Coal Mining & 15 & 17 & 21 & 21 & 23 \\
\hline 2 & $\begin{array}{l}\text { Crude Petroleum and Natural } \\
\text { Gas }\end{array}$ & 6 & 7 & 7 & 8 & 8 \\
\hline 3 & Metal and Mineral Mining & 5 & 6 & 7 & 8 & 8 \\
\hline 4 & Land / Stone Quarrying & 3 & 2 & 2 & 2 & 2 \\
\hline$\quad$ Total & 29 & 32 & 37 & 39 & 41 \\
\hline
\end{tabular}

Source: Processed data, 2016. follows:

While the population details of Trade, Service, and Investment Companies are as 
Table 6 - Population of TSI Companies listed on IDX in 2010-2014

\begin{tabular}{|c|c|c|c|c|c|c|}
\hline No & Subsector & $' 10$ & '11 & '12 & '13 & '14 \\
\hline 1 & Wholesale & 29 & 30 & 33 & 34 & 33 \\
\hline 2 & Retail trade & 18 & 20 & 21 & 22 & 21 \\
\hline 3 & Restaurant, hotel, and tourism & 23 & 23 & 21 & 20 & 21 \\
\hline 4 & Advertising, printing and media & 10 & 11 & 12 & 13 & 14 \\
\hline 5 & Health care & 1 & 1 & 2 & 3 & 4 \\
\hline 6 & Computer and service & 7 & 5 & 4 & 5 & 5 \\
\hline No & Subsector & 10 & '11 & 12 & 13 & 14 \\
\hline 7 & Investment company & 7 & 8 & 10 & 11 & 11 \\
\hline 8 & Others & 2 & 3 & 4 & 4 & 5 \\
\hline & Total & 97 & 101 & 107 & 112 & 114 \\
\hline
\end{tabular}

Source: Processed data, 2016.

The sampling method in this research is purposive sampling, means the establishment of samples is based on specific criteria. The criteria of samples are as follows:

1. Public Mining Companies and Trade, Service, and Investment Companies that are listed in the Indonesia Stock Exchange in 2010-2014;

2. The companies that has published its financial reports continuously throughout the research period that is 2010 to 2014;

3. Companies that have positive net income throughout the research period that is 2010 to 2014 ;

4. Companies that distribute dividends continuously throughout the research period that is 2010 to 2014.

The process of taking samples by using the criteria shown in the following table.

Table 7 - Sampling by Using the Criteria

\begin{tabular}{|c|l|c|c|}
\hline No & \multicolumn{1}{|c|}{ Criteria } & MNG & TSI \\
\hline 1 & $\begin{array}{l}\text { Public Mining and TSI Companies that are listed in the Indonesia Stock Exchange } \\
\text { continuously in 2010-2014 }\end{array}$ & 34 & 81 \\
\hline 2 & $\begin{array}{l}\text { The companies that has published its financial reports continuously throughout the research } \\
\text { period that is 2010 to 2014 }\end{array}$ & 34 & 81 \\
\hline 3 & Companies that have positive net income throughout the research period that is 2010 to 2014 & 19 & 77 \\
\hline 4 & $\begin{array}{l}\text { Companies that distribute dividends continuously throughout the research period that is 2010 } \\
\text { to 2014 }\end{array}$ & 6 \\
\hline
\end{tabular}

Source: Processed data, 2016.

Table 7 above stated that the selected sample in this research are 6 Mining Companies for 5 years, that is 30 pooling data and 6 Trade, Service, and Investment Companies for 5 years that is 30 pooling data. The following table lists sample of this research.

Data Collection Method. Data used in this research is secondary data that derived from Indonesia Stock Exchange (IDX) performance summary and audited company's financial report. Based on the dimensions of time, this study is cross-sectional and time series. Data obtained using the data collection techniques www.idx.co.id and audited company's financial report. The variable data sources used in this research are summarized in table 8 below:

Table 8 - Variable Data Sources

\begin{tabular}{|c|c|c|}
\hline No & Indicator & Data Source \\
\hline \multicolumn{3}{|c|}{ LEVERAGE } \\
\hline \multirow[t]{3}{*}{1} & Debt Ratio (DR) & IDX \\
\hline & Debt Equity Ratio (DER) & IDX \\
\hline & Long Term Debt per Total Asset (LTDA) & IDX \\
\hline \multicolumn{3}{|c|}{ DIVIDEND POLICY } \\
\hline \multirow[t]{3}{*}{2} & Dividend Per Share (DPS) & IDX \\
\hline & Dividend Payout Ratio (DPR) & IDX and audited financial report \\
\hline & Dividend Yield (DY) & IDX \\
\hline \multicolumn{3}{|c|}{ FINANCIAL PERFORMANCE } \\
\hline \multirow[t]{3}{*}{3} & Return on Equity (ROE) & IDX \\
\hline & Return on Asset (ROA) & IDX \\
\hline & Net Profit Margin (NPM) & IDX \\
\hline
\end{tabular}

Source: Processed data, 2016. 
Data Analysis Method. Statistical analysis used that accordance with the research questions, research objectives, and the research hypothesis is Generalized Structured Component Analysis (GSCA). The purpose of GSCA is to replace factor with linear combination of indicator (manifest variables) in the SEM analysis. Tenenhaus (2008) (in Solimun, 2013) states that GSCA is a new method of SEM-based components, it is very important and can be used for score calculation (not scale) and can also be applied to very small samples. Besides, GSCA can be used on structural models that involve variable with reflexive or normative indicator. In addition, GSCA also allows the occurrence of multicollinearity, the occurrence of strong correlation between exogenous variables, unlike the covariance-based SEM which singularity and multicollinearity remain become an obstacle. In the research discussion section, the analysis will be separated each sector.

\section{RESULTS AND DISCUSSION}

The Weight Factor of Indicator. This research uses weight factor to measure the significance of variable's indicators. The larger the size of the weight factor, the more important the indicators are interpreting the variables. Hair (2007) stated that weight factor more than 0.3 is considered to meet the minimal level for interpretation of structure.

Below is the leverage weight factor of Mining and TSI companies.

Table 9 - The Leverage Weight factor of Mining Companies

\begin{tabular}{|c|c|c|c|c|}
\hline \multirow{2}{*}{ No } & \multirow{2}{*}{ Indicators } & Weight & CR \\
\cline { 3 - 5 } & & -0.327 & 0.591 & 0.55 \\
\hline 1 & DER & 1.088 & 1.116 & 0.97 \\
\hline 2 & DR & 0.297 & 0.401 & 0.74 \\
\hline 3 & LTDA & &
\end{tabular}

Source: GeSCA result.

Table 10 - The Leverage Weight factor of TSI Companies

\begin{tabular}{|c|c|c|c|c|}
\hline \multirow{2}{*}{ No } & \multirow{2}{*}{ Indicators } & Weight & CR \\
\cline { 3 - 5 } & & Estimate & 0.497 & 1.33 \\
\hline 1 & DER & -0.662 & 0.679 & 2.39 \\
\hline 2 & DR & 1.621 & 0.243 & 0.27 \\
\hline 3 & LTDA & -0.065 & \\
\hline
\end{tabular}

Source: GeSCA result.

Below is the dividend policy weight factor of Mining and TSI companies.

Table 11 - The Dividend Policy Weight factor of Mining Companies

\begin{tabular}{|c|c|c|c|c|}
\hline \multirow{2}{*}{ No } & \multirow{2}{*}{ Indicators } & Weight & SE \\
\cline { 3 - 5 } & & Estimate & 0.953 & 1.43 \\
\hline 1 & DPS & 1.358 & 0.523 & 0.98 \\
\hline 2 & DPR & -0.513 & 0.389 & 0.75 \\
\hline 3 & DY & -0.292 & \\
\hline
\end{tabular}

Source: GeSCA result.

Table 12 - The Dividend Policy Weight factor of TSI Companies

\begin{tabular}{|c|c|c|c|c|}
\hline \multirow{2}{*}{ No } & \multirow{2}{*}{ Indicators } & \multicolumn{3}{|c|}{ Weight } \\
\cline { 3 - 5 } & & Estimate & SE & CR \\
\hline 1 & DPS & -0.448 & 0.521 & 0.86 \\
\hline 2 & DPR & 0.127 & 0.574 & 0.22 \\
\hline 3 & DY & 0.993 & 0.883 & 1.12 \\
\hline
\end{tabular}

Source: GeSCA result. 
Below is the financial performance weight factor of Mining and TSI companies.

Table 13 - The Financial Performance Weight factor of Mining Companies

\begin{tabular}{|c|c|c|c|c|}
\hline \multirow{2}{*}{ No } & \multirow{2}{*}{ Indicators } & \multicolumn{3}{|c|}{ Weight } \\
\cline { 3 - 5 } & & Estimate & SE & CR \\
\hline 1 & NPM & -0.598 & 0.523 & 1.14 \\
\hline 2 & ROE & -1.607 & 1.327 & 1.21 \\
\hline 3 & ROA & 2.917 & 2.164 & 1.35 \\
\hline
\end{tabular}

Source: GeSCA result.

Table 14 - The Financial Performance Weight factor of TSI Companies

\begin{tabular}{|c|c|c|c|c|}
\hline \multirow{2}{*}{ No } & \multirow{2}{*}{ Indicators } & \multicolumn{3}{|c|}{ Weight } \\
\cline { 3 - 5 } & & Estimate & SE & CR \\
\hline 1 & NPM & 1.083 & 1.192 & 0.91 \\
\hline 2 & ROE & -1.047 & 1.506 & 0.69 \\
\hline 3 & ROA & 0.765 & 2.317 & 0.33 \\
\hline
\end{tabular}

Source: GeSCA result.

General Structure Component Analysis:

Table 15 - Model Fit

\begin{tabular}{|c|c|c|}
\hline No & \multicolumn{2}{|c|}{ MODEL FIT } \\
\hline 1 & FIT & 0.712 \\
\hline 2 & AFIT & 0.695 \\
\hline 3 & NPAR & 30 \\
\hline
\end{tabular}

Source: GSCA analysis result.

Table 15 states that FIT value of this reseach is 0.712 . The FIT values range from 0 to 1 , the larger FIT value, the more variance in the variables is accounted for by the model. It means the variables contained in this research model is able to explain the phenomena by $71.2 \%$, whether the remaining $28.8 \%$ is explained by another variables.

Hypothesis Testing on Mining Companies. Below is the research result of GeSCA path coefficient analysis in Mining Companies:

Table 16 - Path Coefficient of Mining Companies

\begin{tabular}{|c|l|c|c|c|c|}
\hline $\mathrm{H}$ & \multicolumn{1}{|c|}{ Path } & Estimate & SE & CR & Description \\
\hline $\mathrm{H} 1 \mathrm{a}$ & Leverage $\rightarrow$ Dividend Policy & 0.640 & 0.453 & 1.41 & Insignificant \\
\hline $\mathrm{H} 1 \mathrm{~b}$ & Dividend Policy $\rightarrow$ Leverage & 0.481 & 0.318 & 1.51 & Insignificant \\
\hline $\mathrm{H} 2 \mathrm{a}$ & Leverage $\rightarrow$ Financial Performance & -0.637 & 0.143 & $4.46^{*}$ & Significant \\
\hline $\mathrm{H} 2 \mathrm{~b}$ & Financial Performance $\rightarrow$ Leverage & -1.094 & 0.158 & $6.94^{*}$ & Significant \\
\hline $\mathrm{H} 3 \mathrm{a}$ & Dividend Policy $\rightarrow$ Financial Performance & 0.512 & 0.244 & $2.1^{*}$ & Significant \\
\hline $\mathrm{H} 3 \mathrm{~b}$ & Financial Performance $\rightarrow$ Dividend Policy & 1.167 & 0.496 & $2.35^{*}$ & Significant \\
\hline $\mathrm{CR}^{*}=$ significant at .05 level & \multicolumn{5}{ll}{} \\
\hline
\end{tabular}

\section{Source: GeSCA Result}

This research shows three hypotheses to test. Hwang (2011) stated that CR is used for testing the significance of an estimate and CR larger than two is roughly normal. The test results on the Mining Companies shows that there is one hypothesis $\left(\mathrm{H}_{1}\right)$ that has $C R<2$, thus the hypothesis is rejected, that is hypothesis $\mathrm{H}_{1 a}$ with path Leverage to Dividend Policy and $\mathrm{H}_{1 \mathrm{~b}}$ Dividend Policy to Leverage. Both paths have insignificant $\mathrm{CR}$, those are 1.41 and 1.51. 


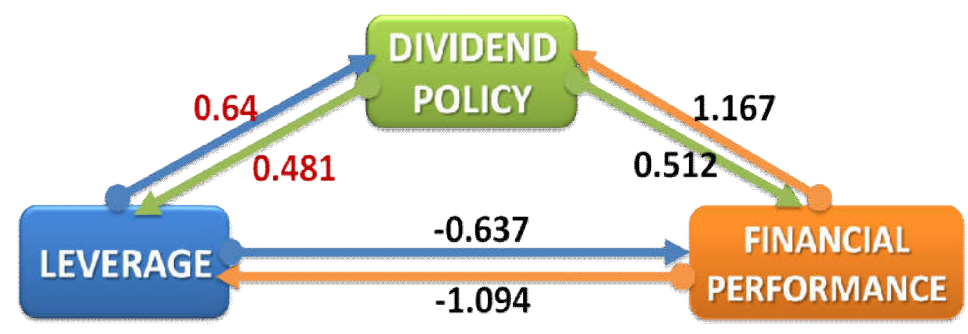

Source: Processed Data, 2016.

Figure 3 - Path Coefficient Diagram of Mining Companies

In conclusion, based on figure 3 and the description above, the results of research hypothesis testing on Mining Companies are as follows:

$\mathrm{H} 1$ : Leverage has insignificant effect on dividend policy reciprocally;

$\mathrm{H} 2$ : Leverage has significant effect on financial performance reciprocally;

H3: Dividend policy has significant effect on financial performance reciprocally.

Hypothesis Testing on Trade, Service, and Investment Companies. Below is the research result of GeSCA path coefficient analysis in Trade, Service, and Investment companies.

Table 17 - Path Coefficient of Trade, Service, and Investment Companies

\begin{tabular}{|l|l|l|l|l|l|}
\hline $\mathrm{H}$ & \multicolumn{1}{|c|}{ Path } & \multicolumn{1}{|c|}{ Estimate } & \multicolumn{1}{c|}{ SE } & \multicolumn{1}{c|}{ CR } & \multicolumn{1}{c|}{ Description } \\
\hline $\mathrm{H} 1 \mathrm{a}$ & Leverage $\rightarrow$ Dividend Policy & 1.090 & 1.361 & 0.8 & Insignificant \\
\hline $\mathrm{H} 1 \mathrm{~b}$ & Dividend Policy $\rightarrow$ Leverage & 0.389 & 0.539 & 0.72 & Insignificant \\
\hline $\mathrm{H} 2 \mathrm{a}$ & Leverage $\rightarrow$ Financial Performance & -0.872 & 0.128 & $6.79^{*}$ & Significant \\
\hline $\mathrm{H} 2 \mathrm{~b}$ & Financial Performance $\rightarrow$ Leverage & -0.924 & 0.157 & $5.88^{*}$ & Significant \\
\hline $\mathrm{H} 3 \mathrm{a}$ & Dividend Policy $\rightarrow$ Financial Performance & 0.393 & 0.479 & 0.82 & Insignificant \\
\hline $\mathrm{H} 3 \mathrm{~b}$ & Financial Performance $\rightarrow$ Dividend Policy & 1.165 & 1.457 & 0.8 & Insignificant \\
\hline $\mathrm{CR}^{*}=$ & significant at .05 level
\end{tabular}

Source: GeSCA Result.

The test results on the TSI companies shows that there are two hypotheses that have $\mathrm{CR}<2$, thus the hypothesis are rejected, that is hypothesis $\mathrm{H}_{1}$ with path Leverage to Dividend Policy $(C R=0.8)$, Dividend Policy to Leverage $(C R=0.72)$, and hypothesis $\mathrm{H}_{3}$ with path Dividend Policy to Financial Performance $(C R=0.82)$ and Financial Performance to Dividend Policy $(\mathrm{CR}=0.8)$.

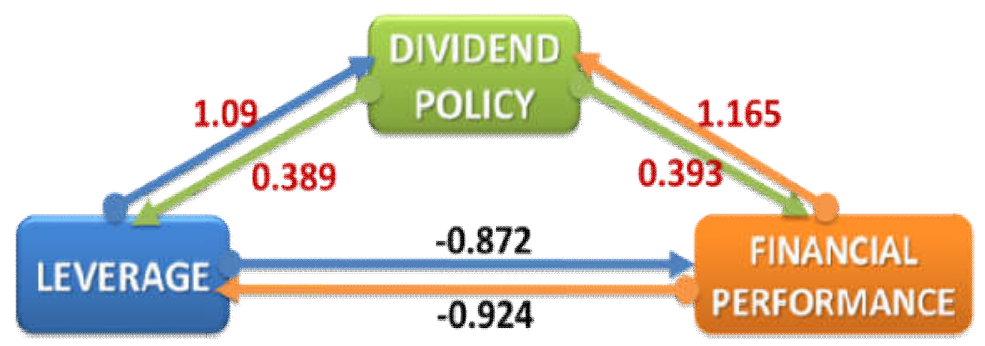

Source: Processed Data, 2016.

Figure 4 - Path Coefficient Diagram of Trade, Service, and Investment Companies

In conclusion, based on figure 4 and the description above, the results of research hypothesis testing on Trade, Service, and Investment Companies are as follows:

$\mathrm{H} 1$ : Leverage has insignificant effect on dividend policy reciprocally;

$\mathrm{H} 2$ : Leverage has significant effect on financial performance reciprocally;

H3: Dividend policy has insignificant effect on financial performance reciprocally. 


\section{RESULTS AND DISCUSSION}

The Effect of Leverage on Dividend Policy. The result of path analysis on GSCA shows that Leverage has insignificant effect on Dividend Policy in Mining Companies. This result is not accordance with Debt Covenant Hypothesis that Leverage has significant effect on Dividend Policy. Based on Debt Covenant Hypothesis, the creditor constraints dividend payments because it has potential wealth transfer from the bondholders to stockholders. Thus, it makes a company that has high level of Leverage tends to pay less dividend because of dividend payment constrains.

However, based on GSCA on Mining Companies the relationship is insignificant. It because Mining Companies have relatively small average Debt Ratio, the significant Leverage indicator, which is 0.42 , also lower than TSI companies, thus it has insignificant effect on Dividend Policy, because since the Debt Ratio is low, then the constrain degree is low.

The result of path analysis on GSCA also shows that Leverage has insignificant effect on Dividend Policy in Trade, Service, and Investment Companies. The significant Leverage indicator for TSI companies is Debt Ratio. This result is also not accordance with Debt Covenant Theory as stated above. TSI Companies have the lowest liabilities of all sectors listed on Indonesia Stock Exchange with average around Rp 1.652 billion, compared with Mining's that have the highest liabilities, which is Rp 6.555 billion. Since that, the Leverage of TSI Companies is not significant enough to affect its Dividend Policy.

According to descriptive analysis, both Mining and TSI Companies have high dividend distribution, Mining Companies have the higher DPS (the significant dividend indicator) and TSI companies have the higher DY (the significant dividend indicator). Thus, the reason why GSCA result is insignificant is because there are factors other than Leverage that could affect Dividend Policy. Since dividend payment is important informational tool for the company to the market as a signal that company is in a good condition (Bhattacharya, 1979) company invest their money to dividend distribution rather than get a "punishment" from the stockholders by selling their shares in hands to the market, so the supply and demand theory would be applied, if the company's stock supply is higher because the shareholders sell it on the basis of punishment it will cause the stock price go down. Attah-Botchwey (2014) stated in his research result that firms with higher dividend payment have their share price going up in a result of higher demand of shares, whether firms with lower dividend have their share price going down. Losses due to a decrease in market value is greater than the dividend that should be paid.

Mining and TSI Companies have the same results which is Leverage has insignificant effect on Dividend Policy. This research results are consistent with the previous researches such as Emamalizadeh, et al (2013); Khan (2013); Hussain and Usman (2013); and Rizqia (2013) that stated Leverage have insignificant effect on Dividend Policy. Although those researchers study in difference sectors such as Food, Chemical, Pharmaceutical, and Manufacturing Companies with different countries such as Tehran, Pakistan, and Indonesia, the result is the same, which is Leverage has insignificant effect on Dividend Policy.

The Effect of Dividend Policy on Leverage. GSCA shows that Dividend Policy of Mining Companies' has insignificant effect on its Leverage. This result is not accordance with Monitoring Hypothesis that Dividend Policy has positive effect on Leverage as stated by Suhadak and Darmawan (2011). On Monitoring Hypothesis, if company owe money, creditors will help shareholders to monitor managers' behavior, thus the managers do not do things arbitrarily on the basis of perceived personal gain which could loss the company. In this manner, shareholders could decrease the agency cost that previously appeared before creditor monitoring, because the stockholders do less monitoring activity towards the managers. If dividend distribution increases, the company free cash flow will be decrease, and need external funding such as leverage to run the business. That is why company pay out dividends and owe money at the same time.

TSI companies' dividend policy has insignificant effect on its leverage. This result is also not accordance with monitoring hypothesis. Trade, service, and investment companies 
have low liabilities that it is not enough for the creditor to monitor manager's behavior. Besides, based on Sudarma et al. (2014) the structure of public company ownership in Indonesia, around $71 \%$, tend to concentrated and to be controlled by the institution rather than managerial and public, thus the managers is appointed by the majority ownership, which means that agency cost would less happened. With institutional ownership, companies do not need another parties controlling the manager because the agency problem tend to be low.

The Effect of Leverage on Financial Performance. GSCA shows that the effect of Leverage on Financial Performance of Mining Companies is significant and negative. This result in some extent is not accordance with Trade-off Theory. Trade-off Theory stated that there are benefits to Leverage within a capital structure until the optimal capital structure is reached. The theory recognizes the tax benefit from interest payments because issuing bonds effectively reduces a company's tax liability. However, the marginal benefit of further increases in liabilities is declines as liabilities increases, while the marginal cost remains increases.

The effect of TSI companies' leverage on its financial performance is significant and negative. This result is also not accordance with Trade off theory that leverage has positive effect on financial performance.

The Effect of Financial Performance on Leverage. The effect of Mining Companies' financial performance on its leverage is significant and negative. TSI companies' financial performance on its leverage is also significant and negative. This result on both Mining and Trade, Service, and Investment Companies is accordance with Pecking Order Theory that financial performance affects the leverage since companies with high level of financial performance or profitability will have low levels of debt, because high profit company has a lot of internal source of funds and need less debt. This research result is consistent with Amidu (2007).

The Effect of Dividend Policy on Financial Performance. The effect of Mining Companies' dividend policy on its financial performance is significant and positive. This result is accordance to the Bird in The Hand Theory that increasing dividend payment associated with increases financial performance because a higher current dividend distribution reduces uncertainty about company's future cash flow. In order to prevent the managers to use company's plenteous free cash flow for low risks projects or negative NPV projects, it would be better to distribute it as dividend.

GSCA shows that the effect of TSI companies' Dividend Policy on its Financial Performance is insignificant. This research result is not according with Bird in the Hand Theory. As stated above that dividend distribution is capable to prevent the managers to use company's plenteous cash for low risks projects or negative NPV projects that could decrease company Financial Performance. However, based on empirical evidence, TSI companies have no plenteous cash ( $R p$ 1,767,626 M) and it was smaller than Mining companies (Rp 3,194,066 M)

The Effect of Financial Performance on Dividend Policy. The effect of Mining Companies' financial performance on its dividend policy is significant and positive. This result is accordance to Dividend Signaling Theory that financial performance has positive effect on dividend policy. Because company with good financial performance can send signals to the market through dividends and firms with poor financial performance cannot imitate these because of the extravagant signaling cost such as transaction cost of external financing, dividend tax, and distortion of investment decisions. The first consideration of perspective shareholder to invest in a company is its financial performance ratio such as ROE, ROA, and NPM, because company with good profitability is capable to distribute dividends.

The effect of TSI companies' financial performance on its dividend policy is insignificant. This result is not accordance to the signaling theory that financial performance has significant positive effect on dividend policy. There are many factors other than financial performance that can affect dividend policy.

There are some other reasons why company distribute / not distribute dividend. Based on Tax Preference Theory (Litzenberger and Ramaswamy, 1979), companies better to not 
distribute dividend because first, dividend has higher tax rate than capital gain, and second, it is better for companies to reinvest rather than distribute it to shareholder, because re-invest company free cash flow to profitable project capable to increase company financial performance. The other reasons based on Residual Dividend Theory stated that dividend should be distributed only if the investment requirements have already met by maintaining a desirable debt equity ratio. Also there is Catering theory by Baker and Wurgler (1994) which states that a decision by managers to pay dividends is affected by the demand / investor sentiment towards cash dividends and the magnitude of investor demand for cash dividend varies every time.

Research Limitation. The limitations of this research are as follows:

This research is expected to study about Dividend Policy of high and low liabilities company, but only few of the population companies are distributing dividend, thus the sample is limited;

The variable indicators are expected to represent the variable but based on GeSCA, only few of them is significant.

Suggestions. Based on the findings and limitations of the research, suggestions for further research and stakeholders are as follows:

It would be better if the research is expanded into other sector companies, especially that distribute dividend thus it is expected to gain more samples;

It would be better to add more indicators for each variables thus it is expected to get more significant indicators.

\section{CONCLUSION}

This research is empirically examined the effect of leverage, dividend policy, and financial performance reciprocally and to know the difference application on the companies that have high and low liabilities level in Indonesia. The object of this research is using publicly traded companies listed in Indonesia Stock Exchange (IDX) in period of 2010 - 2014 of Mining Companies which has the highest average corporate liabilities of all sectors and Trade, Service, and Investment Companies which has the lowest average corporate liabilities. The research analysis using GSCA (Generalized Structured Component Analysis). The research results show that leverage has insignificant effect on dividend policy reciprocally both on Mining and Trade, Service, and Investment companies. Leverage has significant effect on the financial performance reciprocally both on Mining and Trade, Service, and Investment Companies. Dividend policy has significant effect on the financial performance reciprocally on mining companies. However, Dividend policy has insignificant effect on the financial performance reciprocally on trade, service, and investment companies.

\section{REFERENCES}

1. Adedeji, A. (1998). Does The Pecking Order Hypothesis Explain the Dividend Payout Ratios of Firms in The UK? Blackwell Publishers Ltd. Journal of Business Finance and Accounting, pp. 1127-1155.

2. Al-Malkawi, H.A.N. (2008). Factors Influencing Corporate Dividend Decision: Evidence from Jordanian Panel Data. International Journal of Business, 13(2).

3. Amidu, M. (2007). How Does Dividend Policy Affect Performance of the Firm On Ghana Stock Exchange?. Investment Management and Financial Innovations, 4(2).

4. Ardestani, H.S. (2013). Dividend Payout Policy, Investment Opportunity Set and Corporate Financing in the Industrial Products Sector of Malaysia. Journal of Applied Finance and Banking, 3(1): 123-136.

5. Asif, A., Rasool, W., Kamal, Y. (2011). Impact of Financial Leverage On Dividend Policy: Empirical Evidence from Karachi Stock Exchange-Listed Companies. African Journal of Business Management, 5(4): 1312-1324. 
6. Borges, M.R. (2008). Is the Dividend Puzzle Solved?. Working papers ISSN No 08744548. Department of Economics. School of Economics and Management. Technical University of Lisbon.

7. Baker, M., Wurgler, J. (1994). A Catering Theory of Dividends. The Journal of Finance, 59(3): $1125-1166$.

8. Bhattacharya, S. (1979). Imperfect Information, Dividend Policy, and "The Bird in the Hand" Fallacy. The Bell Journal of Economics, 10(1): 259-270. The RAND Corporation.

9. Brigham, E. (1999). Financial Management: Theory and Practice. Ninth Edition. Harcourt College Pub.

10. Devi, B., Prayogo, D. (2013). Mining and Development in Indonesia: An Overview of the Regulatory Framework and Policies. IM4DC Action Research Report.

11. Business Monitor International. (2012). Indonesia Mining Report Q3 2012. Business Monitor International, London.

12. Darmawan, A. (2011). Pengaruh Sumber Pendanaan, Struktur Kepemilikan Saham, Diversifikasi, Faktor Eksternal Terhadap Dividen, Investasi, Nilai Perusahaan. Unpublished Dissertation. Business Administration, Faculty of Administration Science, University of Brawijaya, Malang.

13. Sudarma, M., Dewi, D.M., Djumahir, Sukoharsono, E.G. (2014). CSR Effect On Market and Financial Performance. International Journal of Business and Management Invention, 3(1): 56-66.

14. Easterbrook. (1984). Two Agency-Cost Explanations of Dividends. The American Economic Review, 74(4); 650-659.

15. Emamalizadeh, M., Ahmadi, M., Pouyamanesh, J. (2013). Impact of Financial Leverage on Dividend Policy at Tehran Stock Exchange: A Case Study of Food Industry. African Journal of Business Management, 7(34): 3287-3296.

16. Gordon, M.J. (1963). Optimal Investment and Financing Policy. Journal of Finance, pp. 264-272.

17. Hair, J.F.J. (2007). Multivariate Data Analysis. $7^{\text {th }}$ edition. Pearson Prentice Hall.

18. Hussain, M., Usman, M. (2013). Investment Opportunities and Dividend Yield (Evidence from KSE). International Journal of Multidisciplinary Sciences and Engineering, 4(11).

19. Kalay, A. (1982). Stockholder-Bondholder Conflict and Dividend Constraints. Journal of Financial Economics, 10: 211-233. North-Holland Publishing Company.

20. Khan, W. (2013). Impact Assessment of Financial Performance and Leverage on Dividend Policy of Pakistan Chemical and Pharmaceutical Industries. Middle-East Journal of Scientific Research, 16(10): 1376-1382.

21. Lieokomol, P. (2011). ASEAN Mining Opportunities AIMEX 2011. Australian Trade Commission.

22. Lintner, J. (1962). Dividends, Earnings, Leverage, Stock Prices, and the Supply of Capital to Corporations. Review of Economics and Statistics, pp. 243-269.

23. Litzenberger, R.H., Ramaswamy, K. (1979). The Effect of Personal Taxes and Dividend on Capital Asset Prices: Theory and Empirical Evidence. Journal of Finance Economics, 7(2): 163-195.

24. Miller, M.H., Modigliani, F. (1961). Dividend policy, growth, and the valuation of shares. Journal of Business, 34(4): 411-433. University of Chicago Press.

25. Mosavi, S.A., Honarbakhsh, S., Ghaedi, M. (2012). Ownership Structure and Dividend Policy Evidence from The Tehran Stock Market. African Journal of Business Management, 7(25): 2432-2443.

26. Myers, S. (1984). The Capital Structure Puzzle. The Journal of Finance, 39(3): 575-592.

27. Myers, S.C., Majluf, N. (1984). Corporate Financing and Investment Decisions When Firms Have Information That Investors Do Not Have. Journal of Financial Economics, 13: 187-221. North-Holland Publishing Company.

28. Purnomosidi, L. (2014). Pengaruh Ukuran Perusahaan, Struktur Modal, Good Corporate Governance, dan Fundamental Makro Terhadap Kinerja Keuangan Serta Implikasinya Pada Nilai Perusahaan. Unpublished Dissertation. Business Administration, Faculty of Administration Science, University of Brawijaya, Malang. 
29. Rizqia, D.A., Aisjah, S., Sumiati. (2013). Effect of Managerial Ownership, Financial Leverage, Profitability, Firm Size, and Investment Opportunity on Dividend Policy and Firm Value. Research Journal of Finance and Accounting, 4(11).

30. Siahaan, U.M. (2014). Pengaruh Ukuran Perusahaan dan Struktur Modal Terhadap Likuiditas, Kinerja Keuangan dan Nilai Perusahaan Pada Kelompok Perusahaan Besar dan Kecil. Unpublished Dissertation. Business Administration, Faculty of Administration Science, University of Brawijaya, Malang.

31. Solimun. (2013). General Structural Component Analysis. Presented at the research methodology training - the GSCA application.

32. Subramaniam, R.K., Shaiban, M.S. (2011). Investment Opportunity Set and Dividend Policy in Malaysia: Some Evidence On the Role of Ethnicity and Family Control. 2nd International Conference on Economics, Business and Management. IACSIT Press, Singapore.

33. Suhadak, Darmawan, A. (2011). Pemikiran Kebijakan Manajemen Keuangan. $1^{\text {st }}$ edition. Okani Bukaka, Malang.

34. Syamsuddin, L. (2007). Manajemen Keuangan Perusahaan: Konsep Aplikasi dalam Perencanaan, Pengawasan, dan Pengambilan Keputusan. PT Raja Grafindo Persada, Jakarta.

35. Yegon, C. (2014). Effects of Dividend Policy on Firm's Financial Performance: Econometric Analysis of Listed Manufacturing Firms in Kenya. Research Journal of Finance and Accounting, 5(12).

36. Yulianto, A. (2014). Pengaruh Struktur Kepemilikan, Good Corporate Governance, Struktur Modal, dan Kebijakan Dividen Terhadap Nilai Perusahaan. Unpublished Dissertation. Business Administration, Faculty of Administration Science, University of Brawijaya, Malang.

37. Vo, D.H., Nguyen, Van T.Y. (2014). Managerial Ownership, Leverage and Dividend Policies: Empirical Evidence from Vietnam's Listed Firms. International Journal of Economics and Finance, 6(5). Canadian Center of Science and Education. 